\title{
THE ROLE OF CAMP IN PROMOTING THE PARTICIPANTS' SPOKEN ENGLISH EXPRESSION
}

Jalaluddin
STKIP Paracendekia NW Sumbawa
(jalaluddinak@gmail.com)

\begin{abstract}
Thestudy investigated the topics of participants' spoken expressionin an English camp and how the topics were discussed.A case study was applied as the research design. Data were gained from focus-group interviews, observation, and questionnaire. The results showed that the participants talked about various topics, which could be categorized into two types i.e. guided topics and situational topics. Guided topics were discussed by the participants in guided conditions. On the other hand, situational topics appeared naturally with respect to the situation. The data also indicated that the activeness and confidence of the participants to talk in English gradually increased during the English camp. The findings suggested that English campsbeheld regularly as they can boost the participants' English speaking skill.
\end{abstract}

Key words: English camp; spoken English expression

\begin{abstract}
ABSTRAK
Studi ini bertujuan untuk melihat topik-topik percakapan bahasa Inggris peserta English camp dan bagaimana topik-topik tersebut didiskusikan. Studi kasus diterapkan dalam penelitian ini. Data dikumpulkan melalui interview, observasi, dan angket. Hasil penilitian menunjukkan bahwa peserta membicarakan beragam topik selama berada di English Camp. Topik-topik tersebut secara garis besar dapat dikategorikan menjadi dua jenis, yaitu guided topics dan situational topics. Guided topics umumnya dibicarakan oleh peserta dalam kondisi yang sudah diatur. Sedangkan situational topics dibicarakan oleh peserta secara alami berdasarkan kondisi ketika mereka sedang berbicara. Data juga menunjukan bahwa keaktifan dan kepercayaan diri peserta untuk berbicara dalam bahasa Inggris secara perlahan-lahan meningkat selama English camp. Disarankan dari hasil penelitian ini agar English camp dapat diadakan secara berkala karena terbukti dapat meningkatan kemampuan berbicara bahasa Inggris peserta.
\end{abstract}

Kata kunci: English Camp; ungkapan berbicara bahasa Inggris

How to Cite: Jalaluddin. (2015). The Role of Camp in Promoting the Participants' Spoken English Expression. IJEE (Indonesian Journal Of English Education), 2(1), 45-57. doi:10.15408/ijee.v2i1.1433

Permalink/DOI: http:/ /dx.doi.org/10.15408/ijee.v2i1.1433 


\section{INTRODUCTION}

The use of modern communicative language teaching approaches in the language classroom and the widespread use of English have increased the demand to learn good communication skills (Tanveer, 2007).

In Indonesia, although English is learntfrom the elementary up to the high school anduniversity levels, the ability of learners to master Englishspecifically in communicative skills is still dissappointing. Dardjowidjojo (2000) discovered that a high school graduate in Indonesia is not able to communicate in English intelligibly. In other words, formal education is still unsuccessful to facilitate the students mastering English quite satisfactorily.

Some authors have offered their explanations and suggestions regarding the issue. Moedjito (2008) argues that this issue has brought the pedagogical implication, i.e. the revision of the process and objective of teaching English as both a second language (ESL) and as a foreign language (EFL). Salwa (2014) suggests that teaching English as a foreign language requires serious struggle because it is not used in the daily life. Some other factors such as theteachers' low level of competency, limited resources and the low motivation of students to learn English are assumed to also contribute to such condition (Samuel, 2000).

From a linguistic perspective, as stated by Samuel (2000), the problem of English teaching and learning in Indonesia is more specifically related to lexical and grammatical issues. Lexical properties encompass not only phonological and meaning but also grammatical aspects. In connection with this, the exposure to English in natural setting gives more significant effects to the acquisition of lexicon compared to the formal instruction. The language input is very needed by the learners rather than learning the grammatical aspect. In this case, the teacher should serve as a facilitator in the process whereby the input of language is being acquired. In other words, it is suggested that teachers be responsible for creating a new environment,which will facilitate learners to get access to practice the target language at maximum.

According to Jazadi (2008), Indonesia should apply learnercentered theoryin teaching English to cope with the learners' failure. The theory proposes that the learners should be guided to become independent learners. In this way, they can benefit their time and use their environment as effective and efficient as possible to learn English. 
For the most part, to make learning a second or foreign language successful, the target language environment should be created for the learners and the teachersare responsible for creating such a situation. Ismail and Tahir (2011) argue that teaching and learning process involve both indoor and outdoor activities. In addition, they consider that any activity could be useful for students especially when they positively perceive and appreciate the content. Therefore, the exposure to the target language is the most important factor in determining the success of studying a new language. In other words, the more learners are exposed to the target language, the more fluent they will be.

In the effort to provide large exposure of English to the students, STKIP Paracendekia NW Sumbawa (NTB) initiated an English camp program in 2013 to facilitate learners to communicate in English in all their time. This program is supported by a regulation, which obliges students not to speak other languages. Hence, the natural exposure to English environment is provided in this program. The camp activities were categorized into two types i.e. semiformal activities and free activities. Semi-formal activities were instructed by the assistant of English department.
Meanwhile, free activities run normally in respect of the participants' routine. Later on, this program becomesan annually mandated program for the English department. According to the syllabus, the camp aims at training the students to communicate effectively, be able to cooperate among themselves, and develop leadership skills. Basically, the most emphasized point is the creation of spoken English atmosphere.

Generally, the existence of English camp is intended to create supportive milieu for studying English. As claimed by Cho (2004), English camp program is designed to increase the opportunities for students to communicate one to another in English naturally, to promote self-confidence among the students to speak English, and to prepare students to live in global community. Myeong and Seong (2011) claim that the intensive English camp at home guided by the English teachers can create learning as well as supporting social environment. Learning context leads the students to engage with language input and output as well as to involve them in language forms and the improvement of linguistic competence. Similarly, supporting social environment contributes to the students' wide use of second language (L2) as a tool of communication. In this condition, the 
learners are guided to recognize the real function of the language in social context as well as the way of authentic interaction. By combining these two kinds of context, the learners are expected to have skillful competence in English.

Ellis (1986) stated that many evidences show the input of L2 can only happen as the learners have access to the L2. The form of input can be the learners' exposure in a given setting or natural setting. In learning L2 in natural setting, the learners will use the language freely and spontaneously. This situation can make the learners' enthusiasm increase in communication.

As reported by Wighting, Nisbet, and Tindall (2006) in their findings on investigating an English camp in China, the major advantage of English camp is that students show high motivation to speak English. By the same token, Halvorsen (2005) considers that there are three main reasons why English Camp is positively influential for the English learners. Firstly, it is enjoyable for both the participants and organizers. The enjoyable condition is the main element to increase motivation and continue English study. In the second place, the organizers can focus on one aspect of language learning such as pronunciation, writing, or they can accommodate all four skill areas into one activity. Thirdly, the informal camp atmosphere helps students relax. As they focus on communication, they are greatly encouraged to use English.

Wighting et al. (2006) claim that students in English camp have a large opportunity to practice English conversation one to others within various meaningful contexts, such as:

1. Interaction in various setting (educational and social);

2. Cooperative work with others (face-to-face, dyads, small or large groups);

3. Enjoyable activities to do interaction (singing, sport, drama, games, and formal and informal conversation);

4. The process of English acquisition through direct teaching; and

5. Establishing relationship via social interaction.

The students' interaction within the camp is divided into two types namely educational and social interaction. Educational interaction is practiced under the process of classroom activities. The materials that students receive from their classrooms are implemented in their social interaction. Hence, the students can internalize more deeply English spoken expression. The students are also 
guided to be able to establish strong cooperation through group activities. As additional activities, the instructors commonly do singing, dancing, game, drama and so forth which are very enjoyable for the students. Such conditions will lead the students to be motivated. During English camp, the students potentially show their improvement on their English acquisition. Similarly, Ismail and Tahir (2011) emphasize that English camp focus on enhancing the participants' essential English skills such as communicating effectively, cooperating among themselves and developing leadership ability, cultivating a sense of responsibilities, developing a sense of belongings, and promoting creativity and critical thinking.

For the most part, English camp program is aligned with the concept of language immersion. A developmental report (Pacific Policy Research Center, 2010) states that language immersion is a concept of teaching language, usually a second language (L2), in which the target language is used as both curriculum content and media of instruction. The method in language immersion focuses on using the target language as a teaching tool, involving or "immersing" students in the L2 environment. In other words, the learners are involved in the situation where they feel that they can meet the target language around them. Furthermore, Rugasken and Harris (2005) in their study claim that when talking about language immersion, the main concern is how to teach a second or foreign language to students by immersing them in the target language. They are positioned in contextual learning as they have experienced when acquiring their first language (L1). By applying the concept of language immersion, in-class activities in different subjects such as math, science, social studies, history, and those outside of the class such as meals or everyday tasks, are conducted in the target language.

Immersion programs can be grouped based on age and extent of immersion (Mangubhai, 2005). In terms of age, learners are divided into three types. The first is early immersion, where the learners start learning the second language from age 5 or 6 . The second is middle immersion, where learners start learning the second language from age 9 or 10. The last one is late immersion, where learners start learning the second language between ages 11 and 14 .

Concerning extent, there are various types as described in the following. 
Total immersion: $90 \%$ of class time is used in the foreign language. Subject materials are taught in foreign or target language.

Partial immersion: $50-75 \%$ of the class time is spent on learning subject matter in the foreign language.

Two-way immersion (dualor bilingual immersion): the population of learners encompasses speakers of two languages. Another term for this kind of immersion program is called bilingual education. Bilingual education can be categorized as the model of education involving two languages as media of instruction (Christian \& Genesee, 2001).

Content-based foreign languages in elementary schools: approximately 15$50 \%$ of class activities is spent in the foreign language and time is spent on learning language as well as learning subject matter in the foreign language.

Foreign languages in elementary schools (FLES) programs: $5-15 \%$ of class activities is spent in the foreign language and time is spent learning it as well as learning subject matter in the foreign language.

In Foreign Language Experience (FLEX) programs, frequent and regular sessions over a short period or short and/or infrequent sessions over an extended period are provided in the second language.

Furthermore, supporting the idea of immersion, Mangubhai (2005) also states that immersion is one of the most effective ways of learning a second language. Marian, Shook, and Schroeder (2013) reported a comprehensive study on the effectiveness of two-way immersion programs on the elementary school students' academic achievement. The result showed that two-way immersion programs benefit academic achievement in both minority- and majority-language students.

Similarly, according to Dulay, Burt \& Krashen (1982), the learning process of L2 is more effective in the natural situation than that in the formal setting. This claim is also supported by the behaviorist learning theory suggested by Ellis (1986). In this theory, the environment has the most significant role in determining the success of the L2 learners.

In the context of STKIP Paracendikia, this program is quite new. So far there has not yet any research that attempts to study this program. Therefore this paper is intented to understand what really happens in the camp. To be more specific, the objectives of this paper are: 
1. to identify the topics of spoken expressionof participants;

2. to explore the conditions when participants express or present specific topics;

3. to investigate the process when participants practice English in the English Camp.

\section{METHOD}

The design of this research was a case study. Singh (2006) contends that a case study is employed only for a specific case. It needs a deep personal observation and intensive study of a phenomenon. Therefore, the field of research is commonly limited but contains deep investigation. In this research, the phenomenon of language immersion in an English camp was mainly explored.

\section{Participants}

The participants in this research were 22 fourth-semester students of English department. They actively joined a three-day English camp in STKIP Paracendekia NW Sumbawa.

\section{Data collection}

The data were obtained through three methods. The first was questionnaire. Faisal (1982) claims that questionnaire can be categorized into two types, close questionnaire and open questionnaire. Close questionnaire is a list of questions that requires short answers from the respondents. On the other hand, open questionnaire requires unlimited answers from the respondents. Open questionnaire was used in this study. The questionnaire consisted of 10 questions that focused on the learners' experience regarding theirspoken topics during the English camp. All the questions required the participants' explanations regarding the focus of the study. The language used in the questionnaire was settled simpler and shorter. It was because of the assumption that most of the participants of the camp were still lack of experience in facing such questionnaire. The questionnaire was given to all participants at the end of the camp. They were instructed not to put their name to guarantee the anonymity.

The second was semi-structured interview. Interview is a conversation between two or more people with a certain purpose (Moleong, 2009). According to Anderson(1998), interview can be used in all sides of the human beings' life of very wide range of intention that requires deep care and skill from the researcher in using it. Semi-structured interview refers to any interview that runs in semi formal situation that can be organized either at 
the participants' home, college, or anywhere relying on their preferences. In this study, the interview wasconductedseveral times until the data was considered enough.The interview consisted of 15 core questions that focused on unearthing the students' experiences regarding their spoken topics in English camp. Taking into account the limitation of the time, only 10 participants were selected as the interviewees. The interview was audio-recorded and noted, while the result of audio-recording was transcribed.The last method was observation. Observation is an activity to look at the object of research directly (Riduwan, 2007).In this study, the focus of the observation was the topic and the process of the discussion during the English camp.

\section{FINDINGS AND DISCUSSION}

During observation, the participants' primary topics of speaking were noted. The particular conditions in which each topic was spoken were also observed and noted. To increase the reliability of the data, similar concern was raised in the interview and questionnaire. The result is shown in Table 1.

Table 1. Topics of Spoken Expression

\begin{tabular}{cll}
\hline No & TOPICS OF SPOKEN EXPRESSION & CONDITION/ACTIVITIES \\
\hline $\mathbf{1}$ & Family & Free time \\
$\mathbf{2}$ & Relationship & Free time \\
$\mathbf{3}$ & Cloth & Free time \\
$\mathbf{4}$ & Body and Health & Free time \\
$\mathbf{5}$ & Occupation & Free time \\
$\mathbf{6}$ & Experience & Free time \\
$\mathbf{7}$ & Feelings & In semi-formal activity and free time \\
$\mathbf{8}$ & Movie (entertainment) & Watching movie and free time \\
$\mathbf{9}$ & Favorite things & Jogging, sport and in free time \\
$\mathbf{1 0}$ & Game & Playing game \\
$\mathbf{1 1}$ & Making Plan & Semi-formal activity \\
$\mathbf{1 2}$ & Food & Cooking and having meal \\
$\mathbf{1 3}$ & Daily activities & Conversation in semi-formal activity and free time \\
$\mathbf{1 4}$ & Expressing like and dislike & Cooking, having meal, and free time \\
$\mathbf{1 5}$ & Transportation tools & Getting ready to go home \\
$\mathbf{1 6}$ & Academic materials & Semi-formal activity and free time \\
$\mathbf{1 7}$ & Sport & When playing \\
$\mathbf{1 8}$ & Joking & Mutual work, sport, and free time \\
$\mathbf{1 9}$ & Environment & Free time \\
\hline
\end{tabular}

The data shows that family by participants in the camp when they related issues was commonly discussed were in their free time. Other topics 
discussed very often by the participants in their free time were relationship, clothes, body and health, occupation, experience, environment, and feeling. In principle, the participants discussed the topics in accordance to the situation they were facing. For instance, the participants were talking about movie as they were watching or after they watched cinema. The data also indicated that they turned their topic to game when they were involved in game. When asked about food, the participants responded that they talked that topic while cooking and having meal. Furthermore, it was found that the participants were talking about favorite things when they did jogging in the morning and also in their free time when they did not perform any particular activity.

In semi-formal activities, the data showed that the participants talked about their daily life and their feeling, discussed learning materials and develop future plan. Meanwhile, issues related to transportation tool appeared when the participants got ready to go home from the camp. The last topic was sport, which was commonly talked when the participants did some sportsin the camp. Sometimes one topic was talked in more than one condition. As can be seen in the Table 2, some topics appeared to be talked in more than one situations. Those topics were feeling, movie, favorite things, food, daily activities, like and dislike, academic materials, and joking.

To summarize, all topics appeared in the English camp can be categorized as guided topics and situational topics. Guided topics in the English camp refer to the topics of spoken expression produced by participants under the guidance of an instructor. Such topics have been predetermined in particular setting.

Situational topics refer to the topics that appear in reference to the situation or condition during the discussion. In the English camp, these kinds of topics were talked in particular conditions or situations. As shown in Table 1, the participants talked about food very often when they were cooking and having meal. Similarly, they talked about game as they were involved in game, about sport when they were having sport, about things related to movies when they were watching movies, and so forth.

Furthermore, as previously mentioned, the topics discussed in both guided and situational conditions are described in the following Table 2. The table informs us that there were more topics discussed in situational condition than in guided context. 
Table 2. Topics of Spoken Expression according to the Type of Condition

\begin{tabular}{clcc}
\hline No & Topics & \multicolumn{2}{c}{ Type } \\
\cline { 3 - 4 } $\mathbf{1}$ & Family & Guided & Situational \\
$\mathbf{2}$ & Relationship & & $\sqrt{ }$ \\
$\mathbf{3}$ & Cloth & $\sqrt{ }$ \\
$\mathbf{4}$ & Body and Health & $\sqrt{ }$ \\
$\mathbf{5}$ & Occupation & & $\sqrt{ }$ \\
$\mathbf{6}$ & Experience & & $\sqrt{ }$ \\
$\mathbf{7}$ & Feelings & $\sqrt{ }$ \\
$\mathbf{8}$ & Movie (entertainment) & & $\sqrt{ }$ \\
$\mathbf{9}$ & Favorite things & & $\sqrt{ }$ \\
$\mathbf{1 0}$ & Game & & $\sqrt{ }$ \\
$\mathbf{1 1}$ & Planning & $\sqrt{ }$ \\
$\mathbf{1 2}$ & Food & $\sqrt{ }$ & \\
$\mathbf{1 3}$ & Daily activities & & $\sqrt{ }$ \\
$\mathbf{1 4}$ & Expressing like and dislike & & $\sqrt{ }$ \\
$\mathbf{1 5}$ & Transportation tools & & $\sqrt{ }$ \\
$\mathbf{1 6}$ & Academic materials & $\sqrt{ }$ \\
$\mathbf{1 7}$ & Sport & & $\sqrt{ }$ \\
$\mathbf{1 8}$ & Joking & & \\
$\mathbf{1 9}$ & Environment & & \\
\hline
\end{tabular}

Concerning the usefullness of the camp, the data gathered from questionnaire and interview revealed that participants responded positively the existance of the English camp. They considered that the English camp was helpful to improve their speaking skill. At first, they contended that English camp program was quite challenging and made them socked to start to communicate or express their daily routine in English.Additionally, from the observation, it was found out that the participants were quite nervous to communicate in the beginning of the camp. They also found it difficult toproduce word by word even they claimed the words were in their mind. They confirmed that the main cause of such difficulty was so far because they merely used English in classroom activities and not in their daily activities. Since the other languages besides English were not allowed to use during the English camp, the participants were forced to use English all the time. Gradually, they began to enjoy the situation as they felt more fluent to speak. The enjoyment was resulted from their feeling of satisfaction as they could practice English in real communication.

Compared with the activities outside the camp, all participants 
agreed that English camp could provide the milieu that enabled them to become active to speak more than in the other sites. Moreover, it was difficult for the participants to find the other locations that could make them active to use English beside in English camp.

Examining the result of the study, three main points are worth mentioning here. First, all topics that generally found in the English camp were basically almost the same as those in natural setting. Second, some typical topics appeared to be discussed by the participants. All in all, few topics were talked in guided condition and the rest appeared in situational context. The third point is regarding the participants' treatment toward their speaking activity during the English camp. In the end of the camp, as shown in Table 2, the findings inform us that there were more topics discussed in situational context than in guided one. This fact shows the students' eagerness to practice their English in real context was more than that in set up atmosphere. It is also interesting to highlight from the findings of the study that the participants' enthusiasm to speak English increased during the
English camp. Wighting et al. (2006) stated that students are highly motivated to speak English in the camp. Firstly, the participants felt quite shock to start conversation in English with their friends. After some time, they were gradually able to talk freely in any condition with free and flowing topics.

\section{CONCLUSION AND SUGGESTION}

As stated in the first chapter, the objectives of this study were to identify the participants' topics of speaking, to explore the situation where the topics appeared and how the participants practiced their speaking skill during the English camp. Based on the findings of the study, there are three conclusions that can be obtained. First, the topics of spoken expression generally found in English camp were various and basically similar to the issues discussed in the natural setting. Second, all topics could be categorized as guided and situational topics. Guided topics were talked within a guided condition, while situational topics were uttered naturally in the alignment with the situation. Last, in 
terms of the process of conversational activities, the participants found it quite challenging and got shock to start communicating in English in the beginning of the camp. Yet, the desire to apply their previous knowledge and skill they got in their regular class into real context resulted in their gradual increase of enthusiasm to communicate in English throughout the camp period.

\section{REFERENCES}

Anderson, G. (1998). Fundamental of education research. London, UK: The Falmer Press.

Cho, M. (2004). A study on the immersion program through English camp in Korea. Kyungpook National University. Retrieved April 27, 2012 from http://www.mendeley.com/rese arch/study-immersion-programthrough-english-camp-korea/.

Christian, D., \& Genesee, F. (2001). Bilingual education: contexts and programs. In D. Christian \& F. Genesee (Eds), Bilingual Education (1-10). South Washington: Teachers of English to Speakers of Other Languages, Inc.
Dardjowidjojo, S. (2000). English teaching in Indonesia. English Australia Journal Winter,18(1), 2230.

Dulay, H., Burt, M.,\& Krashen, S. (1982). Language two. New York: Oxford University Press.

Ellis, R. (1986). Understanding second language acquisation. New York: Oxford University Press.

Ismail, N. S., \& Tahir. I. M. (2011). English camp activities: a strategy to enhance students' English proficiency. Studies in Literature and Language 2(3). 61-72.

Jazadi, I. (2008). The politics of curriculum: an interpretive study of English language teaching and learning at high schools in Indonesia. Sumbawa, NTB: Paracendekia NW Press.

Mangubhai, F. (2005). What can EFL teachers learn from immersion language teaching?. Asian EFL Journal, 7(12), Retrieved March 5, 2012 from http://www.asian-efljournal.com/December_05_fm.ph p.

Marian, V., Shook, A., \& Schroeder, S. R. (2013).Bilingual two-way immersion programs benefit academic achievement. Bilingual 
Research Journal, 36, 167-186.doi: 10.1080/15235882.2013.818075.

Moedjito. (2009). A study on factors determining global intelligibility of EFL learners' Speech. Unpublished Doctoral Dessertation.Hyogo University of Teacher Education, Japan.

Moleong, L. J. (2009). Metodologi penelitian kualitatif. Bandung, Indonesia. PT. Remaja Rosdakary.

Myeong, M., \& Seong, H. (2011). Suggestions for the college intensive English camp program. Paper presented at The 16th Conference of Pan-Pacific Association of Applied Linguistics Conference Program, The Chinese University of Hong Kong, in 8th - 10th August. Retrieved March 31, 2012 from

http://www.paaljapan.org/confe rence2011/ProcNewest2011/pdf/ poster/ Q-10.pdf.

Pacific Policy Research Center. 2010. Successful Bilingual and Immersion Education Models/Programs. Honolulu: Kamehameha Schools, Research \& Evaluation Division.

Riduwan. (2007). Skala pengukuran variabel-variabel penelitian. Bandung, Indonesia: ALFABETA.

Rugasken, K., \& Harris, J. (2005). English Camp: A Language Immersion Program in Thailand. TRAR, 14(2), 43-51.
Salwa (2014). Considerable strategies of teaching large multi-level classes: a narrative study of what EFL teachers should do. Indonesian Journal of English Education, 1(1), 95-105.

Samuel, M. (2000). Problematizing globalization: implications for teaching Global English. In H. W. Kam \& C. Ward (Eds). Language in Global Context: Implication for the Language Classroom (1-13). Singapore: SEAMEO Regional Language Centre.

Sanafiah Faisal. (1982). Metodologi penelitian pendidikan.Surabaya, Indonesia: Usaha Nasional.

Singh, Y. K. (2006). Fundamental of research methodology and statistics. New Delhi, India: New Age International (P) Limited, Publishers.

Tanveer, M. (2007). Investigation of the factors that cause language anxiety for EFL/ESL learners in learning speaking skills and influence it cost on communication in the target language. University of Glassgow. Retrieved July 17, 2011 from http://www.edb.utexas.edu/cscl student/Dhsiao/theories.

Wighting, M. J., Nisbet. D. L., \& Tindall, E. R. (2006). Exploring a summer English language camp experience in China: a descriptive case study. Asian EFL Journal, 9(1), 1-26. 